\title{
ČETRTA GENERACIJA VOJSKOVANJA 3. del: NOV KONCEPT SV ZA DELOVANJE $\checkmark$ ČETRTI GENERACIJI VOJSKOVANJA
}

\section{FOURTH GENERATION WARFARE Part 3: NEW SAF CONCEPT OF OPERATIONS IN FOURTH GENERATION WARFARE}

Povzetek V članku obravnavamo koncept lahke pehote in njeno vlogo v četrti generaciji vojskovanja, kot je bila opredeljena v prejšnjih prispevkih. Sodobno razumevanje lahke pehote je pogosto zavajajoče in neskladno z zgodovinskim razumevanjem pojma in koncepta lahke pehote. Podrobneje so predstavljene glavne značilnosti prave lahke pehote in zakaj te povsem ustrezajo potrebam četrte generacije vojskovanja. Ugotavljamo tudi, na kakšnih izkušnjah bi SV lahko utemeljevala svojo povezanost s konceptom klasične lahke pehote, in ponudimo enega izmed mogočih pristopov $\mathrm{k}$ spremembi organizacijske kulture, če bi ta želela prevzeti bistvene značilnosti lahke pehote. Nazadnje obravnavamo še nekaj elementov organizacije in strukture, ki bi $\mathrm{v}$ povezavi s konceptom lahke pehote ustrezali potrebam SV za delovanje v četrti generaciji vojskovanja.

Ključne Lahka pehota, frontna pehota, organizacijska kultura, četrta generacija besede vojskovanja.

Abstract The article presents the light infantry concept and its role in fourth generation warfare as defined in author's previous articles. Classical light infantry has a specific set of characteristics and the way NATO looks at it is not in accord with them and a historical perspective on light infantry. The article discusses in detail the key characteristics of light infantry and how they relate to fourth generation warfare. It also looks at how the SAF is related to the concept of light infantry, and how it should change its organizational culture if it wants to impregnate itself with light infantry mentality. Lastly, it looks at some elements linked to SAF organization and structure related to the concept of light infantry and fourth generation warfare.

Key words Light infantry, line infantry, organizational culture, fourth generation warfare. 
Uvod $» / . . . /$ The cold, brutal fact is that much present-day military power is simply irrelevant as an instrument for extending or defending political interests over most of the globe; /... When it comes to preventing acts of terrorism closer to home, the military services and their arms - fighter bombers, tanks, armored personnel carriers, etc. are even less useful.« (van Creveld, 1991, str. 27) ${ }^{1}$

Do zdaj smo lahko ugotovili, da bodo za uspešno delovanje v četrti generaciji vojskovanja $(4 \mathrm{GW})$ nujne resne spremembe organizacijske kulture ${ }^{2}$ na ravni celotnega nacionalnovarnostnega sistema, sicer tvegamo, da bomo nerelevantni, ne le znotraj zavezništva, temveč tudi pri soočanju z grožnjami, ki jih prinaša vojna četrte generacije.

Oborožene sile bodo morale narediti nekaj najtežjih korakov, pri tem bo moralo vodstvo najprej postaviti jasno definirane okvire nujnih sprememb. Tudi če so imela vodstva Slovenske vojske že v preteklosti iskrene namene po resnični transformaciji vojske v sodobno, profesionalno in na nove izzive pripravljeno silo, je treba stvarno ugotoviti, da v svojih namenih niso bila uspešna. Tega ni mogoče zanikati. Poročila vrhovnemu poveljniku o pripravljenosti $\mathrm{SV}$ to neizpodbitno dokazujejo. ${ }^{3} \mathrm{Ob}$ tem menimo, da je organizacijska kultura v SV spremembam izrazito nenaklonjena. ${ }^{4}$

V tem prispevku se bomo osredotočili na spremembe, ki so po našem mnenju nujne, da bi se vojske lahko spopadale s širokim spektrom groženj, ki jih prinaša četrta generacija vojskovanja. Menimo, da je pravilen pristop h konceptu lahke pehote ena izmed možnosti, kako oborožene sile preoblikovati v silo, sposobno spoprijemanja z vsem, kar to vojskovanje prinaša. Zavedamo se, da ima zamisel veliko gorečih nasprotnikov, prepričani pa smo, da ta nasprotovanja izhajajo predvsem iz nerazumevanja in nepoznavanja tega, kaj je prava organizacijska kultura lahke pehote. Zato menimo, da je najprej treba jasno opredeliti in razumeti bistvo lahke

\footnotetext{
»Mrzla, kruta resnica je, da je večina današnje vojaške moči preprosto irelevantna kot orodje projekcije ali obrambe političnih interesov po svetu. /.../ Ko gre za preprečevanje terorističnih dejanj doma, so zvrsti in njihovi rodovi - lovski bombniki, tanki, oklepni transporterji - še manj uporabni.«

2 Organizacijska kultura je sestavljena iz treh elementov, in sicer artefaktov, vrednot in prepričanj, ter temeljnih predpostavk. Pri tem so artefakti to, kar je na zunaj vidno, pri vojski so to npr. uniforme, bojni prapori in bojna sredstva. Vrednote in prepričanja obstajajo na dveh ravneh, in sicer to, kar je kot vrednota deklarirano, in to, kar je kot vrednota resnično razumljeno (prepričanje). Zaželeno bi bilo, da je to dvoje usklajeno, pa vendar ni vedno tako. In ne nazadnje so tu temeljne predpostavke, ki predstavljajo najpogosteje nezavedno podlago, na kateri je zgrajena organizacijska kultura.

3 http://www.delo.si/novice/politika/ocena-pripravljenosti-sv-slabsa-kot-leto-prej.html http://www.up-rs.si/up-rs/uprs.nsf/objave/730A776D0942B9BEC1257E54003EDE90?OpenDocument http://www.24ur.com/novice/slovenija/pahor-slovenski-vojski-podal-nezadostno-oceno.html

Poročila o pripravljenosti SV že več let zapored kažejo njeno nezadostno pripravljenost za izvrševanje najpomembnejših zakonsko določenih nalog (ZObr, 37 člen). Iz sporočil za javnost lahko sklepamo, da je glavni vzrok pomanjkanje finančnih sredstev. Menimo, da je to zavajajoče. Finančni viri so seveda pomembni in brez njih se sistem težko razvija, toda za spremembe v sistemu niso bistveni. Bistveno je razumevanje varnostnega okolja in kulturnih, organizacijskih, strukturnih in drugih sprememb, potrebnih za uspeh v novem varnostnem okolju. Za uresničenje sprememb so bistveni želja, sposobnost in znanje.

${ }^{4}$ Da bi to lahko potrdili, bi bila nujna raziskava organizacijske kulture in njene naklonjenosti spremembam. Dokler takšne raziskave ni, gre zgolj za avtorjeva osebna občutja in opažanja, pridobljena z metodo udeležbe.
} 
pehote. Predvsem je treba povedati, da lahka pehota, ki bi bila učinkovita v četrti generaciji vojskovanja, ni enakovredna temu, kar zavezništvo razume pod tem pojmom, ali temu, kar je bila slovenska TO leta 1991. Pogledali bomo, kaj je treba spremeniti v vojaškem izobraževanju in usposabljanju, da bi lahko oborožene sile preoblikovali v lahko pehoto, kar je izrednega pomena, saj narekuje formalnopravne rešitve, ki opredeljujejo usposabljanje v miru. Brez njihove pravilne opredelitve oboroženih sil ne bomo nikoli pravilno preoblikovali. Spremembe v obsegu in strukturi so manj pomembne kot transformacija v kulturi organizacije, ki mora biti nujno formalnopravno podprta, sicer je obsojena na neuspeh. Nazadnje bomo podali nekaj pogledov na obseg in strukturo SV, temelječih na konceptu lahke pehote.

\section{KONCEPT LAHKE PEHOTE}

\subsection{Lahka pehota proti frontni pehoti}

Po mnenju nekaterih strokovnjakov, pa tudi častnikov SV, naj bi s preoblikovanjem leta 2012 SV dobila značaj lahke pehote. Menimo, da je to daleč od resnice. Polki SV in vojska kot celota niso lahka pehota in to še dolgo ne bodo, vendar zaradi povezave $\mathrm{s}$ pojmom lahke pehote (angl. light infantry) in nepoznavanja zgodovinskih dejstev $\mathrm{v}$ njenem razvoju tudi v strokovni javnosti vlada precejšnja zmeda v razumevanju tega pojma. Dodatno zmedo je vnesel še Nato s svojo klasifikacijo pehote, kot je zapisana v dokumentu Capability Codes and Statements (CC\&S). Nato je že v tem dokumentu poznal pojem light infantry, se nato z novejšo opredelitvijo iz leta 2013 od njega oddaljil in govoril o motorizirani pehoti, da bi z najnovejšo klasifikacijo iz leta 2016 ponovno govoril o light infantry kot posebnem tipu pehotnih enot. Poglede na pojem lahke pehote bi lahko razdelili na dve skupini. V prvi je Natovo oziroma ameriško razumevanje, povezano s konceptom teže in organizacije, posebno tiste, v kateri ni težke opreme, kar ji omogoča veliko strateško mobilnost in odzivnost. V taktičnem smislu pa deluje kot vsaka druga izkrcana pehota. To razumevanje se bistveno razlikuje od druge skupine, ki lahkost razume v odnosu do bojevanja, specifičnega taktičnega sloga in raznolikosti v operativni uporabnosti (Lind \& Thiele, 2015).

Razlikovanje med tako imenovano frontno (angl. line) in lahko (angl. light) pehoto najdemo že v stari Grčiji, v kateri je frontno pehoto predstavljal palax težko oklepljenih in opremljenih pešakov, katerih učinkovitost je temeljila na drilu, množici in šoku. Ob tem je vojsko starih Grkov sestavljala tudi precej obsežna pomožna (lahka) pehota, ki je skrbela za zaščito bokov in je temeljila na hitrosti ter kovinskem orožju ${ }^{5}$. Ta koncept je pozneje izrabila tudi rimska legija, ki je uporabljala lahko pomožno pehoto $\mathrm{v}$ podpori težkim kohortam frontne pehote. $\mathrm{V}$ srednjem veku je bojišče obvladovala konjenica in šele $\mathrm{v} 16$. in 17 . stoletju je počasi ponovno prevladala pehota. V 18. stoletju se je lahka pehota nato začela pojavljati v evropskih vojskah v obliki francoskih chasseur's, pruskih Jaeger- in avstrijskih Grenzer-polkov (Lind \& Thiele, 2015). Te enote so se bistveno razlikovale od strogo discipliniranih enot

5 Lok, kopje, prača. 
težke pehote, saj so bile hitre, okretne in iznajdljive, predvsem pa so lahko delovale neodvisno od logistike glavnine vojske. V obdobju Napoleonovih vojn (1790-1815) se je evropska lahka pehota izjemno razvila, tako da je vključevala lahko artilerijo in lahko konjenico, zato je na bojišču dobivala vse večjo vlogo: kritje umika in napredovanja glavnine, zavajanje nasprotnika, izvidovanje itn. Njena prisotnost je bila občutna pri Ulmu, Jeni, Auerstedtu in med vso Welingtonovo kampanjo v Španiji (McMichael, 1987). S takšno lahko pehoto so se evropska kraljestva borila tudi v Ameriki, zelo zanimive so izkušnje stotnika Johana Ewalda ${ }^{6}$ Evropska kraljestva 18. in 19. stoletja so lahko pehoto dojemala kot nujen način bojevanja, čeprav nevreden pravega vojaka, predvsem zaradi posebnega taktičnega sloga in organizacijske sproščenosti, ki nista ustrezala strogi urejenosti bojišča 18. in 19. stoletja (Selig \& Skaggs, 1991).

Klasični pogled lahko pehoto najprej dojema kot stanje duha in šele nato kot produkt organizacije. Poseben pristop k bojevanju ustvari tudi poseben slog taktike, ki ga običajno ne najdemo v konvencionalni pehoti (McMichael, 1987). Sodoben koncept lahke pehote je razvila vzhodnjaška vojaška teorija 20. stoletja, soočena s tehnološko in materialno premočjo zahodnih vojsk. Med drugo svetovno vojno je imela Japonska taktično najbolje usposobljeno lahko pehoto na svetu, v korejski vojni je Kitajska s svojo pehoto dosegla ravnotežje v boju s tehnično in materialno zmožnejšimi silami OZN (pod vodstvom ZDA), v Vietnamu so ZDA kljub svoji tehnični in materialni moči izgubile, v iraško-iranski vojni smo bili priča spopadu tehnologije s taktiko, brez izrazite premoči ene ali druge strani. Vendar se moramo zavedati, da taktična odličnost ni dovolj proti nasprotniku, ki je pripravljen v spopad vložiti nesorazmerne materialne in človeške vire ${ }^{7}$ in je na operativni ravni vsaj enakovreden, če ne celo boljši ${ }^{8}$ (Poole, 2001).

Klasična lahka pehota ima nekaj resnih omejitev, ki jih moramo razumeti, da bi koncept pravilno prenesli na celotne oborožene sile. Lahka pehota kljub svoji vsestranskosti in prilagodljivosti ni sila za vsako priložnost ali situacijo. V visoko intenzivnem konvencionalnem spopadu ima zelo omejeno uporabnost, saj ji manjka ognjene moči in bojne ter logistične podpore za dolgotrajni bojni stik. Izrazito je ranljiva na artilerijski in letalski ogenj. Neprimerna je za dolgotrajne defenzivne operacije, saj nima logistične infrastrukture za njihovo izvedbo. Manjka ji ognjene moči in vzdržljivosti za napad na utrjene točke, razen kadar ji uspe doseči popolno presenečenje. Na odprtem terenu je zelo občutljiva na hiter manever in večjo ognjeno moč (McMichael, 1987).

\footnotetext{
${ }^{6}$ Treatise on Partisan Warfare (Abhandlung über den kleinen Krieg), prevedeno tudi v angleški jezik, $s$ spremljajočim esejem. V delu je stotnik Ewald J. opisal svoje izkušnje z delovanjem lahke pehote med ameriško vojno za neodvisnost.

Tako Japonci kljub nesporni taktični odličnosti niso zmogli ustaviti napredovanja zahodnih zaveznikov, ki so jih $v$ Indiji številčno osemkrat prekašali (Poole, 2001, str. 6).

${ }^{8}$ Enako Japonci v Mandžuriji niso zmogli ustaviti ruskega oklepnega manevra na operativni ravni (Poole, 2001, str. 5).
} 
Takšno bi torej moralo biti pravilno razumevanje klasične lahke pehote v odnosu do drugih frontnih tipov pehote ${ }^{9}$. Menimo, da sodobno okolje četrte generacije vojskovanja zaradi širokega spektra groženj postavlja koncept klasične lahke pehote v ospredje. Ne zaradi strateške mobilnosti ali (lahke) organizacijske strukture, temveč zaradi organizacijske kulture, ki ustvarja poseben pristop do vojskovanja.

\subsection{Ključne značilnosti lahke pehote}

Značilnosti lahke pehote niso izključno njene in jih lahko v številnih primerih najdemo tudi $\mathrm{v}$ frontni pehoti. Toda bistvene razlike obstajajo, čeprav jih je težko opaziti, ker so sestavni del nevidnega - namreč miselnosti lahkega pehotnika. Različni avtorji (Ewald, Lind, McMichael, Poole in Thiele) značilnosti lahke pehote različno poimenujejo in rangirajo, v splošnem pa lahko izluščimo štiri osrednje značilnosti. Najpomembnejša je samozadostnost (angl. self-reliance), ki je bistvo etosa lahke pehote in izvir, iz katerega se napajajo vse druge njene značilnosti. Samozadostnost se izraža v intelektualni prilagodljivosti in fizični ter psihični trdnosti. Pripadniki lahke pehote so navajeni na asketske razmere in lahko delujejo tudi brez »ugodnosti«, ki jih frontna pehota dojema kot nujne, ter niso psihološko vezani na logistično podporo, predvsem pa ne odnehajo in skušajo do zadnjega obrniti situacijo v svojo korist.

Pristop samozadostnosti omogoča in hkrati zahteva mojstrsko obvladovanje in razumevanje okolja, v katerem delujejo. Ne glede na teren in klimatske razmere je okolje njihov zaveznik, ki jim daje varnost in udobje. Ker so izjemno prilagodljive, te enote obvladujejo teren in ga znajo preoblikovati v taktično prednost. Ker teren in klimo sprejemajo kot naravnega zaveznika, je zanje značilna neprimerljiva taktična gibljivost na zahtevnem zemljišču. Nič ni namreč bolj gibljivega, kot je lahka pehota v gozdu, džungli, hribovitem in goratem svetu ali urbanem okolju.

Obvladovanje zemljišča in samozadostnostvodita knaslednji značilnosti lahke pehote, k vsestranskosti. Ker se je sposobna hitro prilagoditi zemljišču in tipu operacije, je nenadne spremembe v načrtih nikoli ne najdejo nepripravljene. Enote lahke pehote lahko delujejo samostojno ali znotraj večje enote, z elementi bojne podpore ali brez njih. Vsestranskost se kaže tudi v nagnjenosti k improvizaciji in inovacijam. Ker lahka pehota ni strogo vezana na doktrino, lažje razvije nove taktike, inovativno uporablja svojo opremo in se ne obotavlja pri uporabi sovražnikove opreme in virov, ko je treba. Vedno ostaja odprta za nove zamisli, tehnologijo in oborožitev. Bistveno je ohranjanje prilagodljivega odnosa do bojišča.

Vse te značilnosti $\mathrm{v}$ enoti povzročajo zelo visoko zavest kolektiva - esprit de corps. Pripadniki lahke pehote se zavedajo, da so drugačni, ponosni so na to, da delujejo v najzahtevnejšem okolju in najzahtevnejših nalogah. Štejejo se, da so boljši od povprečnega frontnega vojaka in to tudi so. Treba se je zavedati, da se te značilnosti ne razvijejo same po sebi, temveč morajo biti rezultat zahtevnega

9 Glede na staro in novo klasifikacijo pehote v Natu. 
usposabljanja, ustreznega vodenja in opravljenih nalog. Sploh ne smejo biti rezultat česar koli drugega. Poleg teh štirih glavnih značilnosti lahko pehoto determinira tudi poseben odnos do tehnologije, pridobivanja informacij, bojne podpore, logistike in vodstvenega kadra.

Tehnologija ni odločujoči dejavnik delovanja lahke pehote. Tudi če neka tehnologija obstaja, to še ne pomeni, da bo kakor koli prispevala k delovanju lahke pehote. Ognjena podpora s posrednimi ognji za zahteve lahke pehote ne bo vedno učinkovita, prav tako je neuporabna visokotehnološka oprema, ki je pretežka za prenašanje po zahtevnem zemljišču in ne dovoljuje grobega ravnanja. Glavno pravilo pri uporabi novih tehnologij v lahki pehoti je, da je treba te prilagoditi njej in ne obratno. Nikakor pa tehnologija ne sme vplivati na temeljno značilnost lahke pehote-samozadostnost.

Pridobivanje točnih in pravočasnih obveščevalnih informacij je odločilnega pomena za delovanje lahke pehote. Večino uporabnih informacij pridobi sama. Glavni način zbiranja informacij je patruljiranje, ji pa seveda koristijo tudi vsi drugi obveščevalni viri, ne le vojaški, temveč tudi policijski in civilni, zato je ustrezno usklajevanje na tem področju nujno.

Pomemben dejavnik za lahko pehoto je tudi logistika. Logistično načrtovanje vpliva na načrtovanje njenega delovanja, vendar ga ne obvladuje. Da bi se oskrbela, lahka pehota čim bolj izkorišča lokalne vire. Teža individualne opreme je popolnoma prilagojena dejavnikom naloge, sovražnika, zemljišča in vremena. V splošnem velja, da posameznik nosi samo to, kar je nujno ${ }^{10}$. Na tem področju sta seveda zelo dobrodošla sodobna tehnologija in napredek v materialih ter izdelavi prehrambnih izdelkov. Uporaba helikopterja omogoča lahki pehoti samostojno delovanje na večjih razdaljah, daleč od logističnih baz.

Vodje v lahki pehoti so običajno inovativni, prilagodljivi in psihološko trdni. Prenašajo enaka bremena kot preostanek moštva in so zato prav tako dobro telesno pripravljeni in živijo načela samozadostnosti. Vodijo z zgledom in kažejo iskreno skrb za dobrobit svojega moštva, pri čemer ga nikakor ne razvajajo ${ }^{11}$. Predvsem pa ne skrivajo informacij pred njim, temveč skrbijo, da so soborci dobro obveščeni o taktični situaciji in svoji vlogi v njej. Seveda vse te lastnosti najdemo tudi med vodji v drugih tipih pehote in čeprav se vodje v lahki pehoti zdijo nekoliko neortodoksni, je večina, če že ne vsi, enako dobra kot vodje v konvencionalnih enotah.

Lahka pehota se res zanaša predvsem na organsko oborožitev, to pa ne pomeni, da elementi bojne podpore drugih rodov niso dobrodošli ali celo nujni. Predvsem takrat, ko se lahka pehota uporablja za konvencionalne ofenzivne in defenzivne

\footnotetext{
${ }^{10}$ Kaj je nujno, je lahko razumljeno zelo različno, zato imajo tu poglavitno vlogo podčastniki in nižji častniki, ki morajo brezobzirno omejevati to, kar vojaki nalagajo v svoje nahrbtnike. Izkušnje seveda pomagajo, toda vodje morajo nenehno preverjati in prilagajati težo opreme.

${ }^{\prime \prime}$ Kar preprosto pomeni, da bodo naredili vse za čimprejšnjo evakuacijo ranjenih, hkrati pa ne bodo oklevali podaljšati patrulje ali zasede za nekaj dni, če bo imelo to taktični smisel.
} 
naloge. Močna artilerijska podpora in čim več inženirske podpore sta absolutno nujni, ko lahka pehota opravlja klasične defenzivne naloge. Pogosto je smiselno lahko pehoto okrepiti z lahkim oklepom, saj ji to omogoča mobilnost na večjih razdaljah in protioklepne zmogljivosti ter zmogljivost uničevanja utrjenih točk $\mathrm{s}$ težjo oborožitvijo vozil.

Iz poglavitnih značilnosti lahke pehote in njenega odnosa do pomembnih dejavnikov vojskovanja lahko razberemo, da to niso stvari, ki bi bile ekskluzivno povezane z delovanjem lahke pehote. Menimo, da so predvsem štiri ključne značilnosti lahke pehote in njen odnos do voditeljstva to, kar predstavlja bistvo njene organizacijske kulture, prilagodimo pa jih lahko prav vsem tipom pehote. Odnos do tehnologije, bojne podpore, obveščevalne zagotovitve in logistike pa je povezan s posebno vlogo in nalogo različnih tipov pehote ali rodu oboroženih sil v četrti generaciji vojskovanja. $^{12}$

\subsection{Lahka pehota kot odgovor na četrto generacijo vojskovanja}

Četrto generacijo vojskovanja razumemo kot hibridno vojskovanje visoke in nizke intenzivnosti. To je vojskovanje, $\mathrm{v}$ katerem se prepletajo konvencionalne sile in tehnologija z nedržavnimi akterji, kriminalnimi skupinami, delovanjem specialnih sil, informacijskim delovanjem, kibernetskim napadi in drugimi sredstvi asimetričnega vojskovanja.

V teh razmerah sta miselnost lahke pehote in njen pristop do bojevanja, ki ga odlikuje vsestranskost v delovanju, najprimernejša za spopadanje s sovražniki. Menimo, da je miselnost lahke pehote univerzalno uporabna - tudi v motorizirani, mehanizirani in drugi frontni pehoti, artileriji, inženirstvu, kibernetski obrambi in drugih rodovih. Seveda sta lahko znotraj hibridnega vojskovanja intenzivnost in tehnološka raven vojskovanja izjemno različni, kar pa ne pomeni, da je zaradi te različnosti treba vedno znova iskati nov miselni okvir vodenja vojn in vojskovanja. Tak okvir, ki zahteva sposobnost kritične presoje, informirano odločanje in sprejemanje hitrih odločitev (pravilnih), je skupen vsem oblikam hibridnega vojskovanja v četrti generaciji vojskovanja.

Spoprijemanje s četrto generacijo vojskovanja na ravni vodenja vojne zahteva tako obvladovanje tretje manevrske generacije vojskovanja kot miselni okvir, ki razume prave cilje nasprotnika in omogoča pravilne odzive nanj. Na operativni in taktični ravni je lahka pehota tista, ki najbolje odgovarja na večino groženj. Večino groženj v njej namreč predstavlja ravno sovražnik, ki kaže vse lastnosti lahke pehote. Ker celoten spekter vojskovanja v četrti generaciji vključuje tudi težke konvencionalne sile, je nujno zavedanje, da lahka pehota deluje v ciklu štirih korakov: razpršitev, orientacija, koncentracija in akcija (Lind \& Thiele, 2015). Tako je lahko uspešna tudi

\footnotetext{
12 Vezanost mehanizirane pehote na logistično podporo je razumljivo tesnejša kot vezanost kibernetske komponente na sodobno tehnologijo.
} 
v boju z močnejšim konvencionalnim sovražnikom, ko z uporabo taktike infiltracije skuša sovražnika najprej presenetiti in nato premagati v boju na kratke razdalje.

Napačno bi bilo predpostavljati, da zgolj in samo lahka pehota pomeni odgovor na grožnje v četrti generaciji vojskovanja. Ravno nasprotno, še vedno so zelo pomembni tudi mehanizirane sile, artilerija, inženirstvo in drugi rodovi ter službe oboroženih sil, vključno z izjemno pomembnim informacijsko-kibernetskim elementom. Menimo le, da bi bilo treba tudi vse preostale elemente oboroženih sil prepojiti z miselnostjo in organizacijsko kulturo lahke pehote.

\section{SLOVENSKA VOJSKA IN ODGOVOR NA ČETRTO GENERACIJO VOJSKOVANJA}

»Without changing our patterns of thought, we will not be able to solve the problems we created with our current patterns of thought. $\ll^{13}$ (Albert Einstein)

Zgodovinsko gledano imamo Slovenci nekaj mešanih izkušenj z lahko pehoto. Vendar je vse te formacije treba jemati s previdnostjo, ko iščemo primerjave s pravo lahko pehoto. Večinoma so bile te formacije lahke kot Nato danes razume lahko pehoto, kar pa, kot smo že pokazali, ni njena prava odlika.

Oddelki generala Maistra so nastali z razpadom avstro-ogrske vojske ob koncu prve svetovne vojne in so bili v doktrinarnem, organizacijskem in taktičnem smislu njeni nasledniki. Sploh pa niso obstajali dovolj dolgo, da bi se lahko razvili v kaj več. Slovensko domobranstvo je bilo pomožna formacija vojaško-policijskih sil nemške okupacijske vojske na ozemlju Slovenije in je dosledno sledilo doktrini, izobraževanju in usposabljanju nemških sil v drugi svetovni vojni. Udarni domobranski bataljoni so bili nedvomno sposobna vojaška sila in še najbližje tretji generaciji oboroženih sil. Teritorialna obramba RS je bila sestavni del oboroženih sil SFRJ in njenega koncepta splošne ljudske obrambe. Kot tako bi jo težko šteli za pravo predstavnico lahke pehote. Doktrinarno je namreč sledila JLA in tudi njen starešinski kader je bil rezultat sistema izobraževanja in usposabljanja JLA, ki ni bil nujno slab, a se je na koncu izkazala kot tipična predstavnica druge generacije vojsk. Nedvomno je TO opravila pomembno vlogo v osamosvojitveni vojni, ki bi jo po našem mnenju lahko jemali kot zgled vodenja vojne četrte generacije - a zgolj na ravni vodenja vojne. Govoriti o TO kot modelu lahke pehote za četrto generacijo vojskovanja bi bilo narobe in škodljivo, saj za to ni imela ustrezne miselnosti, sistema izobraževanja in usposabljanja ter predvsem starešinskega kadra.

Morda je le partizanska vojska spadala v kategorijo lahke pehote. Kot tipična gverilska vojska niti nima druge izbire, kot uveljaviti koncept samozadostnosti, askeze, obvladovanja zemljišča, prilagodljivosti, operativne vsestranskosti in

\footnotetext{
${ }_{13}$ »Brez spremembe naših trenutnih vzorcev razmišljanja ne bomo nikoli sposobni rešiti težav, ki smo jih ustvarili prav s temi vzorci razmišljanja."
} 
visokega esprit de corps. Če natančneje pogledamo vse značilnosti lahke pehote in njen poseben odnos do bojne podpore, logistike, obveščevalnega delovanja, tehnologije in vodenja, vidimo, da je slovenska partizanska vojska še najboljši približek lahke pehote.

Danes polki SV ne spadajo v Natovo kategorijo lahke pehote. Ta namreč predvideva uporabo vozil z oklepno zaščito Level 1, STANAG 4569. Pehotni polki SV pa vozil praktično nimajo. Sicer v Natu in drugod najdemo prave primere lahke pehote, med katere nedvomno spadajo izraelske in britanske padalske enote (Lind in Thiele, 2015). Da bi polke SV lahko primerjali s temi enotami, ne more biti niti govora. Njihovi standardi izobraževanja in usposabljanja so za polke SV nedosegljivi.

Kot že rečeno, bi bilo napačno lahko pehoto povezovati z lahko oklepno zaščito niti je ne bi smeli razumeti kot zmogljivost s posebnimi selekcijskimi standardi na meji specialnih sil (McMichael, 1987). Tudi če lahka pehota potrebuje zahteven program usposabljanja in odlično vodenje, to ne pomeni, da morajo biti njeni vojaki izbrani s posebnimi selekcijskimi postopki, kakršne poznajo v specialnih silah.

Za delovanje oboroženih sil je bistvenega pomena častniški zbor, ki je nosilec kakršnih koli organizacijskih in kulturnih sprememb. Če torej želimo vzpostaviti oborožene sile na temelju lahke pehote, moramo najprej vzpostaviti ustrezen poklicni sistem izobraževanja in usposabljanja častniškega zbora.

\subsection{Izobraževanje}

Za uspeh v četrti generaciji vojskovanja je bistvena široka razgledanost vodij na vseh ravneh. Kot je dejal že Johan Ewald, »/.../ mora v vojni častnik v lahki pehoti na najnižji ravni početi to, kar general počne na visoki ravni« (Ewald v Selig \& Skags, 1991, str. 64). Da bi to lahko počeli, je treba vodje že v miru ustrezno pripravljati na to.

SV mora postati učeča se organizacija, ki bo gojila in nagrajevala prilagodljivost, inovativnost, kritično razmišljanje, pobudo in samodisciplino. Kultura, ki jo vojska goji v svojem starešinskem zboru, mora biti holistična, usmerjena v profesionalno služenje družbi. Treba je oblikovati starešinski zbor, ki bo v službi družbe kot celote, na to podlago pa dodati »združena« oziroma medrodovsko orientacijo in etos. Šele nato se lahko mladim vodjem začnejo dodajati specializacije, ki bodo definirale individualne kariere (rodovsko kulturo, kulturo posameznega bojiščnega sistema, konvencionalno ali nekonvencionalno kulturo itn.) (Vandergriff, 2006, str. 53).

Prilagodljivost in inovativnost častniškega in podčastniškega kadra sta ključni lastnosti za delovanje v razmerah, ki jih pogojuje četrta generacija vojskovanja. Prilagodljivost se kaže v sposobnosti na hitro prilagajanje različnim situacijam ${ }^{14}$

\footnotetext{
${ }_{14}$ Američani v svoji doktrini govorijo o tako imenovani vojni treh ulic (angl. three block war), pri čemer je treba $v$ prvi voditi konvencionalni spopad, v sosednji protiterorizem in še sosednji mirovno operacijo.
} 
(Vandergriff, 2006, str. 43), ki jo lahko starešinskemu zboru privzgojimo tako, da ga $\mathrm{v}$ procesu izobraževanja čim večkrat soočamo z različnimi nalogami, ki jih mora rešiti, in da vanje sproti vnašamo nove nepričakovane elemente. Inovativnost se doseže tako, da je ljudem dovoljeno poskusiti alternativne načine reševanja in preverjanje zamisli, tudi za ceno neuspeha, in se učiti na podlagi pridobljenih izkušenj. Eksperimentiranje in premišljeno tveganje je treba spoštovati in spodbujati (Vandergriff, 2006, str. 22).

Kritično razmišljanje ne pomeni dvoma v odločitve ali usmeritve nadrejenih, temveč razumevanje skladno s položajem, s katerim je mlad častnik ali podčastnik na terenu soočen. Ta namreč običajno ne dopušča dobesedne interpretacije ukazov, temveč zahteva poglobljeno razumevanje namere nadrejenega. V tem pogledu je upoštevanje poveljevanja z namero (nem. Aufstragtaktik) bistveno. Prav tako je pri izobraževanju starešinskega kadra treba razvijati sposobnost hitrega odločanja na podlagi omejenih ali nepopolnih informacij. Paradigma, da je boljša 80-odstotna rešitev takoj, kot 100-odstotna prepozno, še vedno velja.

Bistvena zahteva za starešine in moštvo $\mathrm{v}$ četrti generaciji vojskovanja je samodisciplina. Samodisciplina pomeni podlago, na kateri se razvijeta prilagodljivost in pobuda. Med profesionalnim izobraževanjem morajo starešine sami ugotoviti, da je potrebna disciplina, če se želijo uspešno spopasti s stresom vadbenih situacij, ki so jim izpostavljeni ${ }^{15}$ (Vandergriff, 2006, str. 88). Nepotrebnih in nesmiselnih pravil se je treba znebiti, vodje pa bi morali dati jasno vedeti, da od moštva pričakujejo visoko raven discipline, ne zaradi kazni, ki bi nedvomno sledile, temveč zaradi želje po dokazovanju (Lind \& Thiele, 2015). Menimo, da sistem izobraževanja in usposabljanja starešinskega kadra v SV ne omogoča oblikovanja vodij, ki bi ustrezali tem zahtevam. ${ }^{16}$ Vprašanje je tudi, če bi bil sposoben uresničiti zgornje zahteve, če bi to nalogo dobil. V SV ni profesionalnih spodbud, ki bi za sistem vojaškega izobraževanja in usposabljanja zagotavljale najboljše kadre. ${ }^{17} \mathrm{Na}$ podlagi sklepov Strateškega pregleda obrambe $2016^{18}$ in osebnih izkušenj menimo, da je rezultat sedanjega vojaškega izobraževanja in usposabljanja v SV zelo nedefiniran vodja.

\footnotetext{
${ }^{15}$ Pri tem je vloga inštruktorjev ključna, saj morajo ves čas paziti na odklone, ki bi pomenili nediscipliniranost, in jih ustrezno sankcionirati. Več primerov navede Vandergriff v svoji knjigi.

${ }^{16}$ Programi usposabljanj starešinskega kadra (podčastnikov in častnikov SV) med cilji poleg drugega navajajo pobudo in prožnost, kar je seveda dobro in skladno s potrebami četrte generacije vojskovanja. Vendar pa je kot vedno težava na izvedbeni ravni, na kateri je veliko odvisno od kakovosti izvajalcev. Poleg tega je težko verjeti, da je pobudo in prilagodljivost mogoče razvijati v okolju, $v$ katerem so vse ure natančno določene in omejene s splošno delovnopravno zakonodajo.

17 Pri tem mislimo na spodbude, ki bi bile privlačne za dobre častnike in podčastnike, ker bi omogočale horizontalno napredovanje in zagotavljale razmere za opravljanje višjih dolžnosti. Vse prave profesije (na primer zdravniki in pravniki) to poznajo. Dokler pa imamo CVS̆ na enem koncu države in sistem, v katerem je mogoče odgovorno poveljniško ali štabno dolžnost opravljati tudi brez opravljene dolžnosti v CVŠ (predavatelj) inštruktor), v sistem vojaškega izobraževanja in usposabljanja ne bomo pritegnili najboljših.

${ }^{18}$ V SPO 2016 je jasno zapisano, da se je po letu 2009 vlaganje v vojaško izobraževanje in usposabljanje zmanjševalo ter da je za izboljšanje razmer $v$ SV nujno izvesti več kratkoročnih ukrepov na tem področju.
} 
Menimo da Center vojaških šol kljub drugačnim deklarativnim normam ne opravlja selekcije mladih podčastnikov in častnikov. ${ }^{19}$ Niti ni v SV enote, ki bi načrtno vzgajala, selekcionirala in razvrščala mlade podčastnike in častnike. Nekdaj je to poizkušal 10. bataljon za mednarodno sodelovanje oziroma 10. motorizirani bataljon, a je sčasoma moral opustiti te selekcijske postopke, zato je izgubil večino posebnega etosa ${ }^{20}$. Da bi lahko ustvarili vodje za četrto generacijo vojskovanja, je nujno kandidate na vseh ravneh izpostaviti visokim standardom, ki bodo od njih zahtevali skrajne psihične in fizične napore. ${ }^{21}$ Še pomembnejši kot visoki psihofizični standardi v sistemu vojaškega izobraževanja in usposabljanja so ustrezni inštruktorski in učiteljski kadri, ki bodo razumeli četrto generacijo vojskovanja in izkazovali značilnosti, ki jih morajo vodje v njej dosegati. V SV je le še ena enota, ki v resnici izpolnjuje zahteve četrte generacije vojskovanja. To so specialne sile SV oziroma Enota za specialno delovanje (v nadaljevanju ESD).

To je enota, ki zaradi narave svojega poslanstva in visokih vstopnih standardov zares goji organizacijsko kulturo lahke pehote, potrebne v četrti generaciji vojskovanja. Njihovo bistveno načelo je osredotočenost na rezultat, med drugim gojijo in cenijo pobudo, prilagodljivost in samodisciplino. Zaradi narave svojega dela delujejo zelo decentralizirano. Nestvarno bi bilo pričakovati ali celo zahtevati, da gredo vsi pripadniki SV skozi selekcijske postopke te enote. Kot je bilo že ugotovljeno, lahka pehota ni nikakršen ekvivalent specialnim silam. Specialne sile imajo svojo vlogo in nalogo v četrti generaciji vojskovanja, preostali elementi oboroženih sil pa svojo. Nujno je le, da se organizacijska kultura osredotočenosti na rezultat, pobude, prilagodljivosti in samodiscipline razširi na celotne oborožene sile. To je mogoče le prek starešinskega kadra ter sistema izobraževanja in usposabljanja. ESD je premajhna in predragocena zmogljivost, da bi jo uporabljali kot nadomestek za Center vojaških šol ( $v$ nadaljevanju CVŠ), ki v resnici predstavlja sistem izobraževanja in usposabljanja starešinskega kadra SV. Kar je nujno, je vzpostaviti formalizirane povezave med ESD in CVŠ, da bi se organizacijska kultura ESD razširila na preostanek SV. Da bi se to sploh lahko zgodilo, je predvsem treba po eni strani resno začeti graditi polne zmogljivosti ESD in po drugi za četrto generacijo vojskovanja uvesti ustrezne selekcijske standarde na vseh ravneh izobraževanja in usposabljanja v CVŠ. Sočasno je treba opredeliti pogoje, ki jih mora izpolnjevati učiteljski in inštruktorski kader CVŠ, da bo na vseh področjih ustrezal zahtevam

\footnotetext{
19 Selekcije šole za častnike in drugih tečajev SV, ki jih opravi $99 \%$ prijavljenih, pač ne moremo šteti kot resne. Tudi tisti, ki se ne odločijo za to delo, običajno ne odpadejo zaradi visokih standardov, temveč zaradi drugih razlogov. O tem, kakšni so pogoji za vpis na štabne in višje štabne tečaje, krožijo »urbane« legende. Če pogledamo starostno strukturo tečajnikov na višjem štabnem tečaju leta 2016, se lahko upravičeno vprašamo, koliko teh ljudi je tik pred upokojitvijo.

${ }^{20}$ Rdeča baretka je nekdaj dokazovala, da je pripadnik uspešno opravil tako imenovano »fazo«, pri čemer med častniki, podčastniki in vojaki ni bilo razlikovanja. Kakršni koli so že bili ti selekcijski standardi in kakor koli so se že uresničevali, je neizpodbitno, da je v enoti in očeh pripadnikov tudi na ta račun vladal poseben etos.

${ }^{21}$ Seveda bi bilo narobe zahtevati nemogoče. Vstopni fizični standardi morajo zagotoviti, da jih bodo opravili samo tisti, ki bodo lahko prenašali bremena četrte generacije vojskovanja. To še ne pomeni, da morajo biti že na vstopni točki sposobni vsega. V tem pogledu je treba znati oceniti potencial in vztrajnost posameznika. Vstopni standardi tudi niso vezani le na fizične sposobnosti, temveč morajo še prav posebej preveriti psihične in intelektualne meje posameznika.
} 
četrte generacije vojskovanja, ter uvesti primerne spodbude za njegovo delo. ${ }^{22}$ Šele nato bi se lahko opredelili učiteljske in inštruktorske dolžnosti, ki jih za določeno obdobje popolnjujejo pripadniki $\mathrm{ESD}^{23}$, in tečaji oziroma programi, ki jih na vseh ravneh šolanja častniškega kadra izvedejo ti pripadniki. Ko bi potrdili prve učinke takšne povezave, bi lahko sistem po vzoru 173ABCT razširili še na povezavo med enoto (polkom) lahke pehote in ESD. ${ }^{24}$

Ob tem seveda ne smemo domnevati, da so samo pripadniki ESD lahko dobri učitelji in inštruktorji v CVŠ. V SV so častniki in podčastniki, ki instinktivno razumejo četrto generacijo vojskovanja in vedo, kakšno znanje je nujno za uspešno delovanje v njej. ESD tudi nima dovolj znanja za vse ravni in vse oblike specialističnega šolanja. Večina učiteljskega in inštruktorskega kadra na CVŠ bo še vedno prihajala od drugod, zato je treba zanj postaviti ustrezne selekcijske standarde pri razumevanju koncepta četrte generacije vojskovanja. Da bi CVŠ in predvsem starešinski kader, ki je tam na izobraževanju in usposabljanju, sprejela ustrezno organizacijsko kulturo in jo vzdrževala, je treba zagotoviti formalizirano, stalno in dovolj veliko prisotnost pripadnikov ESD v CVŠ. Tudi to ne bo imelo ustreznega učinka, če ne bo ustreznih nagrad za opravljanje dolžnosti in kazni, če dolžnosti ne bodo opravljene. ${ }^{25}$

Treba je poskrbeti, da vstop v častniški in podčastniški zbor, torej v voditeljski del vojske, postane težji. Geslo bi moralo biti bolje brez vodje kot s slabim (Vandergriff, 2006, str. 74). Spremembe v organizacijski kulturi so predvsem spremembe v kulturi vojaškega izobraževanja in usposabljanja. Moramo se zavedati, da so predlagane spremembe projekt, ki bi moral trajati vsaj deset let, da bi lahko bil v celoti uspešen.

\subsection{Usposabljanje}

Usposabljanje lahke pehote je zelo zahtevno. Lahka pehota se usposablja v razmerah, ki bi jih najbolje opisali z besedami, kot sta beda in pomanjkanje (McMichael, 1987). Poudarek je na fizični in psihični pripravljenosti na spoprijemanje z najtežjimi nalogami ob pomanjkanju spanca in hrane, pri čemer mora biti pomanjkanje ustrezno dozirano,

${ }_{22} \check{C}$ e na CVŠ ne poskrbimo za kader, primeren za četrto generacijo vojskovanja, je vse drugo zaman. Ključ do uspeha ni toliko v ustreznih selekcijskih standardih za tečajnike kot v ustrezni izbiri učiteljskega osebja na CVS̆. $O$ tem je podrobneje pisal Vandergriff $v$ Breaking the modl.

${ }^{23}$ Te dolžnosti morajo biti strateško izbrane, da bi se organizacijska kultura ESD lahko širila med starešinski kader SV.

${ }^{24}$ V $173 A B C T$ so formalizirana delovna mesta, ki jih za 3-4 leta popolnjujejo pripadniki ameriških specialnih sil. Po opravljeni rotaciji v 173ABCT se ti pripadniki USSOF vrnejo nazaj v specialne sile. Ameriška vojska pozna tudi sistem t. i. Ranger School, ki v nasprotju s splošnim mnenjem ni namenjen usposabljanju enot rangerjev, temveč veliko bolj temu, da se najnižji vodje v ameriški vojski indoktrinirajo z organizacijsko kulturo, ki velja $v$ teh enotah. Namen je, da bi se ta organizacijska kultura prenesla na vso ameriško vojsko, vendar po našem mnenju v tem niso tako uspešni, kot bi lahko bili. Vzroki so v preveliki organizaciji, v kateri se težko ustvari kritična masa častnikov, ki so končali to šolo, s katero bi lahko dosegli pravo spremembo v kulturi organizacije. Poleg tega šola ni del TRADOC in tako niti nima neposredne povezave s sistemom izobraževanja in usposabljanja, ki v resnici oblikuje organizacijsko kulturo starešinskega kadra ameriške vojske. Menimo, da je bistvena razlika med tem, kar predlagamo, in tem, kar lahko vidimo v nekaterih enotah ameriške vojske, ravno v neposredni povezavi med ESD in CVS̆.

${ }^{25}$ Kot je npr. opredelitev zahteve po tem, da vsi bodoči poveljniki polkov (ali enake ravni $v$ SV) na ravni od poveljnika voda do čete prej 3-4 leta poučujejo na CVŠ. 
da se lahko razvije želena odpornost. Druga pomembna prvina usposabljanja lahke pehote je razvijanje pobude, še posebno pri podčastnikih in mlajših častnikih (Lind in Thiele, 2015). Pobuda in prilagodljivost se razvijeta tako, da se v usposabljanje vnašajo nepričakovane zahteve in naloge, ki zahtevajo takojšnji odziv. Patruljiranje in infiltracija sta dve taktični prvini, ki razvijata pobudo. Razvijanje pobude je podobno kot fizično pripravljenost treba vključiti v programe usposabljanja povsod, kjer je mogoče. Pomanjkanje, fizična vzdržljivost in pobuda so tri prvine usposabljanja, ki neposredno prispevajo k razvoju poglavitnih značilnosti lahke pehote.

Urnik usposabljanja mora omogočati tako imenovano usposabljanje brez določenega konca. Usposabljanje se ne konča ob določeni uri ali dnevu, temveč ko je naloga izpolnjena ali standard dosežen. Fizične zahteve usposabljanja morajo biti ves čas na meji mogočega ${ }^{26}$, poudarek pa na vzdržljivostii ${ }^{27}$. Teža opreme ${ }^{28}$ posameznika med usposabljanjem ne sme presegati $22 \mathrm{~kg}$ oziroma 30 odstotkov njegove gole teže. ${ }^{29}$ To je danes praktično nedosegljivo, saj to, kar velja za standardno opremo vojaka, krepko presega predpisano težo. Tudi izkušnje iz sodobnih spopadov kažejo na to, da so vojaki Natovih članic preobremenjeni z opremo, in sicer tako zelo, da to že bistveno vpliva na njihovo učinkovitost. Na tem področju je nujen oster prelom $\mathrm{z}$ željo po absolutni zaščiti vojaka. Posledica te je namreč preobremenjen, neokreten in slabo gibljiv posameznik, ki je fizično izčrpan, še preden vstopi v boj.

Med usposabljanjem je nujna tako imenovana lovska miselnost (nem. Jaegermentalitet). Orientacija na terenu je izjemno pomembna veščina, tako v gozdu kot v mestu, pri čemer jo je treba pri vojakih razvijati brez sodobnih tehnoloških pripomočkov. S tem je povezana tudi veščina nočnega delovanja, pri čemer odsotnost naprav za nočno opazovanje ne more biti izgovor. Lahka pehota je vedno delovala večinoma ponoči, tudi v časih, ko še niso poznali nočnih opazovalnih naprav. Veščino gibanja in delovanja je treba razvijati ob omejeni vidljivosti in tehnologijo vnašati v usposabljanje le, ko je to nujno (Lind \& Thiele, 2015). S pretiranim zanašanjem na nočne opazovalne naprave tvegamo, da bomo ponoči delovali po enakih načelih kot podnevi, kar utegne imeti tragične posledice, ko bomo soočeni s sovražnikom, ki obvladuje nočno delovanje brez uporabe tehnologije.

Za pripadnike lahke pehote ni nujno le poznavanje, temveč tudi obvladovanje vse organske oborožitve enote (oddelek, vod) in obvladovanje osebne oborožitve sovražnika (Lind \& Thiele, 2015).

\footnotetext{
${ }^{26}$ To ne pomeni, da so od začetka do konca fizične obremenitve maksimalno mogoče, pač pa, da so pripadniki oz. enote ves čas obremenjeni z maksimumom njihove trenutne sposobnosti. Usposobljen in izkušen starešinski kader je $v$ tem pogledu nujen.

${ }^{27}$ Trenutno vsakoletno testiranje pripadnikov SV (t. i. PGS oz. Natov test) ne preverja vzdržljivosti, zato ga je treba nadomestiti s testi, ki jo bodo preverjali.

${ }^{28}$ To je teža vsega, kar ima posameznik oblečeno, obešeno in oprtano na sebi, vključujoč spodnje perilo, nogavice, obutev in uniformo, vse do ročne bombe, čelade in neprebojnega jopiča.

${ }^{29}$ Zgodovinske študije so pokazale, da vojaka lahko obremenimo s precejšnjo težo, pa ne bo bistveno izgubil svoje okretnosti (Knapik, 1989). Zgodovinske ugotovitve povzema tudi FM 21-18 (U.S. Army) Foot Marches.
} 
Zagotoviti je treba tudi negotovost logistične zagotovitve usposabljanja. S tem simuliramo okoliščine bojnega delovanja in askezo $\mathrm{v}$ delovanju enote (Lind \& Thiele, 2015). SV se je z razvojem približala miselnosti $\mathrm{FOB}^{30}$, ki je pogubna za delovanje v četrti generaciji vojskovanja.

Večina zahtev, povezanih z usposabljanjem v lahki pehoti, zahteva drugačno pravnoformalno ureditev okolja za usposabljanje SV. Trenutne zakonske omejitve, pa tudi omejitve v podzakonskih aktih, onemogočajo usposabljanje skladno z zgornjimi zahtevami. Te posebne pogoje usposabljanja bi moral prepoznati ustrezen področni zakon in jih nato urediti na način, ki bi omogočal stvarno usposabljanje, hkrati pa bi pri uživanju vseh pravic delavca $\mathrm{v}$ javni upravi zagotovil ustrezen način izravnave zaradi neenakopravnosti vojakov z drugimi javnimi uslužbenci.

\subsection{Organizacija in struktura}

Sile za bojevanje so lahko »lahke« v svoji organizacijski kulturi, tudi če imajo razmeroma težko (oklepno) organizacijsko strukturo. Nemške gorske divizije med drugo svetovno vojno so delovale po načelih lahke pehote, a so bile večje in težje kot standardne pehotne divizije. Organizacijska kultura lahke pehote ni odvisna od njene strukture. Enote so lahko glede na okolje in okoliščine bojevanja notranje zelo različno strukturirane in organizirane. Brigadne in bataljonske operacije lahke pehote so sicer redkejše. Tudi ko je bila zgodovinsko gledano lahka pehota organizirana v brigade in celo divizije, so bile operacije teh enot precej decentralizirane. Splošno gledano je boj v lahki pehoti stvar čete, vodov in oddelkov (McMichael, 1987).

V organizacijski strukturi SV so bile zadnje večje spremembe opravljene s preoblikovanjem leta 2012, pri čemer se pogosto pojavljajo mnenja, da je bilo to preoblikovanje popolnoma zgrešeno (npr. Šavc v Pišlar, 2016, str. 12) ${ }^{31}$. Neustreznost nekaterih sprememb po našem mnenju ni težava nove organizacijske strukture SV, temveč njene organizacijske kulture. Vse preveč se je kot razlog za preoblikovanje poudarjalo pomanjkanje finančnih sredstev, tudi če je to očitno in boleče. Menimo, da SV z več denarja, usmerjenega v nove nakupe, svojih bistvenih pomanjkljivosti ne bi odpravila, le lažje bi jih prikrila pred seboj in javnostjo. Bistvene pomanjkljivosti so namreč $\mathrm{v}$ sistemu izobraževanja in usposabljanja (predvsem častnikov) in $\mathrm{v}$ neprimerni organizacijski kulturi ${ }^{32}$. Te pa je z investicijami v opremo nemogoče popraviti. V povezavi s preoblikovanjem leta 2012 se navajajo štiri velike napake, pri tem pa se pozablja, da preoblikovanje ni bilo izvedeno v vseh načrtovanih fazah.

\footnotetext{
${ }^{30}$ Gre za delovanje, pri katerem enote v operaciji (pa tudi med usposabljanjem) bivajo v velikih bazah (angl. forward operating base), $v$ katerih imajo na voljo vse ugodnosti civilnega življenja in varnost, za katero niso odgovorni sami. To so nekakšni otoki normalnosti na območjih, na katerih normalnost ni naravno stanje.

${ }^{31}$ G. Šavc je, kot je avtorju znano, do zdaj edini javno spregovoril o napakah pri preoblikovanju leta 2012. S tem je odprl možnost za odkrito strokovno javno razpravo, ki prej pač ni bila mogoča.

${ }^{32}$ O ugotovitvah raziskave dr. M. Jakič in o tem, kakšna je organizacijska kultura SV, smo razpravljali v prejšnjem prispevku (Potočnik, 2017, str. 62-63). Če povežemo ugotovitve te raziskave z organizacijsko kulturo za četrto generacijo vojskovanja, vidimo, da je organizacijska kultura SV zanjo povsem neprimerna.
} 
Prva napaka naj bi bila uvedba enakovrednih brigad dvojčic in vzdrževanje dveh poveljniških struktur na ravni brigade. Res je, da je stalne sestave SV primerjalno gledano z brigadami Nata številčno le za slabo brigado, vendar pozabljamo, da doktrinarno brigada SV ni namenjena delovanju v Natu, temveč le na domačem ozemlju. Najmanj, kar to pomeni, je precej manjši logistični podpis brigade SV. ${ }^{33}$ Glavni pozitivni učinek preoblikovanja leta 2012 pa je sposobnost brigade za izvajanje združenega bojevanja rodov, ki je zdaj neprimerno večja, kar dokazujejo usposabljanja in vaje SV po preoblikovanju, na katerih se vsi rodovi usposabljajo skupaj (pehota z inženirci, JRKBO, artilerija). Kar je zdaj pravilo, je bilo pred preoblikovanjem izjema in je neposredna posledica spremenjene organizacijske strukture brigad. Očitek, da se zdaj vzdržujeta dve poveljniški strukturi na brigadni ravni, spregleduje, da je imela SV že pred preoblikovanjem dve brigadni poveljstvi in poveljstvo brigade vojnega letalstva.

Naslednja napaka naj bi bila ukinitev poveljstva sil kot poveljstva na operativni ravni. Menimo, da $\mathrm{v}$ resnici to ni bilo načrtovano in da se $\mathrm{z}$ vzpostavitvijo Združenega operativnega centra (ZOC) to tudi ni zgodilo. V SOPR 2013-2018 je ta center jasno opredeljen kot poveljstvo operativne ravni, ki bo »pristojno za poveljevanje in kontrolo pripravljenim silam doma in silam, ki delujejo v tujini, ter za kratkoročno načrtovanje in samostojno vodenje aktivnosti« (SOPR, 2013, str. 18). V veljavnem SOPR 2016-2018 je zapisano, da bo SV »organizirana tako, da bo zagotavljala delovanje na strateški, operativni in taktični ravni« (SOPR, 2016, str. 35). Z nadaljevanjem preoblikovanja leta 2017 bi bili lahko priče ponovni uvedbi poveljstva operativne ravni, pri čemer pa GŠSV kot poveljstvo strateške ravni žal ni integriran v MO, kar je bil eden ciljev preoblikovanja leta 2012 in kar je zapisano tudi v veljavni ReSDPRO 2025 (str. 55).

Razpustitev rodovskih bataljonov, predvsem bataljona JRKBO, naj bi bila prav tako napaka. Menimo, da o tem v SV prevladuje največja mogoča demagogija in čeprav se strinjamo s tem, da je bila uporaba uravnilovke napaka, nismo povsem prepričani, da je bila napaka v celoti. Rodovski bataljoni so danes predstavljeni kot začetek in konec strokovnosti. Menimo, da se stroka ne razvija v enotah, razvija se s profesionalnim sistemom vojaškega izobraževanja in delujočimi štabnimi organi na generalštabu, ki skrbijo za razvoj rodov. V enotah pa se stroka izvaja. In če vzamemo doktrinarno predpostavko brigadne bojne skupine kot najvišje oblike bojnega delovanja v SV, se za marsikateri rod zastavlja vprašanje smiselnosti organizacije na bataljonski ravni. Predvsem so to bataljon JRKBO, vojaška policija, zračna obramba in zveze. Vse te enote na bataljonski ravni namreč bistveno presegajo doktrinarne potrebe SV. ${ }^{34}$ Če bi razmišljali znotraj koncepta lahke pehote, sta vprašljiva tudi artilerija

\footnotetext{
${ }^{33}$ Logistični bataljoni na ravni brigade v ZDA predstavljajo $28 \%$ (HBCT), $23 \%$ (IBCT) in $17 \%$ (SBCT) moštva celotne brigade. Na ravni manevrskih bataljonov poveljniško-logistični elementi predstavljajo približno $30 \%$ moštva bataljonov (FKSM, 2010). Seveda to ne pomeni, da so brigade SV lahko toliko manjše. Še vedno tudi za delovanje v RS potrebujejo logistično zagotovitev, a ta je lahko neprimerno manjša.

${ }^{34}$ Ob tem se zavedamo, da je res vprašanje, kako smiselna je bila ukinitev bataljona JRKBO. Ne, ker bi ga SV potrebovala, ampak zato, ker je bila zmogljivost za zavezništvo zgrajena in je bilo vanjo vloženo veliko sredstev.
} 
in inženirstvo. Seveda se vedno najdejo razlogi, ki opravičujejo obstoj teh enot na bataljonski ravni, na primer z zavezami do Nata ali s potrebami zaščite, reševanja in drugih elementov nacionalnovarnostnega sistema. Tem argumentom seveda ni mogoče oporekati, le da nimajo nobene zveze z vojaško stroko. Če je z vidika drugih elementov nacionalnovarnostnega sistema (zunaj SV) obstoj teh enot na bataljonski ravni nujen, je treba to tako tudi zapisati in prek teh elementov tudi zagotoviti vire za njihov obstoj. Po našem vedenju v SV tudi nikoli ni bila opravljena resna strokovna razprava z zavezujočimi sklepi, ki bi obravnavala problematiko rodov. ${ }^{35}$ Vsekakor ni bila ponujena na vpogled širši strokovni javnosti.

Centralizacija oklepnih vozil v tako imenovani avtopark je zadnji veliki očitek preoblikovanju leta 2012, ki se pojavlja. Tu se strinjamo z oceno nekaterih, da se zamisel ne zdi skladna z našo miselnostjo, res je tudi, da jo opuščajo tudi druge vojske. Toda to ne opravičuje odklonov na izvedbeni ravni (namernih ali nenamernih), ki se ne bi smeli zgoditi in so v resnici onemogočile uresničljivost zamisli (avtopark bi moral imeti mehanike, ne pa voznikov in namerilcev). Poleg tega se je SV tu srečala tudi s posledicami dolgoletne nenapisane kadrovske politike, po kateri je vse, kar ni bilo dovolj dobro ali zanesljivo za bojne enote, končalo v logistiki ali vojaškem šolstvu - seveda s svetlimi izjemami. Drugo je, da je za delovanje avtoparka potreben kulturni preskok, za katerega se zdi, da se ga SV niti ne zaveda.

Če kaj, je bila napaka, da je bil pristop k ukinjanju rodovskih enot (tudi pehote) egalitaren (če enega, potem vse), brez resne analize potreb in izvedljivosti. Predvsem pa je bilo preoblikovanje prehitro, čeprav so zanj nedvomno obstajali razlogi. Zdi se, da je bilo podobno tudi s pripravo strateškega pregleda obrambe za leto 2016. To sicer ne pomeni nujno, da je izdelek slab, vendar hitenje pri njegovi pripravi vzbuja najmanj dvom v kakovost izvedbe. Kot da se nismo ničesar naučili. Če je zamisel nastala v glavah vodij, to še ne pomeni, da je uresničljiva. Da to postane, jo je treba ustrezno predstaviti podrejenim, ki jo morajo sprejeti za svojo, sicer se srečamo z nepotrebnim odporom, nerazumevanjem in celo nagajanjem.

Nekaterim domnevnim napakam, nastalim v preoblikovanju 2012, smo se posvetili, ker menimo, da pri razmišljanju o strukturi in organizaciji SV znotraj četrte generacije vojskovanja ne moremo mimo tega, da bodo potrebne velike kulturne, organizacijske in strukturne spremembe, nepripravljenost nanje pa je posledica odpora do preoblikovanja leta 2012.

\subsection{Popolnjevanje}

Kot smo že ugotovili, sedanji sistem popolnjevanja ne zagotavlja dovolj moštva niti za trenutno dovoljeni obseg SV, kaj šele za morebitno rast vojaške strateške rezerve. $\mathrm{S}$ tem se bo treba sprijazniti in čim prej ugotoviti, da kozmetični popravki zakona o obrambi in drugih podzakonskih aktov, s katerimi naj bi izboljšali status vojaka, ne

${ }_{35}$ Dopuščamo sicer možnost, da se je to zgodilo in so rezultati teh razprav nekje v arhivu. 
bodo zadostovali. SV mora spremeniti sistem popolnjevanja, da zagotovi ustrezen obseg za delovanje v četrti generaciji vojskovanja.

Stalna sestava bi morala zadoščati za oblikovanje vojaško relevantnih zmogljivosti, za katere smo se zavezali zavezništvu. Poleg tega je treba računati tudi z institucionalnim deležem, ki je nujen in bo zadostoval tudi za potrebe rezervne sestave. Tu se je treba zavedati, da želena piramidna struktura $\mathrm{v}$ odnosu častniki, podčastniki in vojaki v stalni sestavi ne bo nikoli mogoča. Pozabljamo namreč, da vojska za svoje delovanje, ne glede na obseg oziroma število bojnih enot taktične ravni, potrebuje nekatere podsisteme za svoj obstoj in delovanje. ${ }^{36}$ To so zelo pomembni podsistemi, kot so vojaško izobraževanje in usposabljanje, znanstvenoraziskovalne dejavnosti, poveljevanje in kontrola idr., brez katerih vojske v pravem pomenu besede ne more biti, ki zahtevajo ustrezno število strokovno primernih častnikov in podčastnikov. ${ }^{37}$ Ob tem se pogosto pozablja, da tudi Teritorialna obramba RS ni bila samostojna organizacijska enota, temveč se je v izobraževalnem, znanstvenoraziskovalnem, razvojno-tehničnem in mnogih drugih pogledih v celoti opirala na sisteme JLA.

Lahka pehota tudi ne izključuje naborništva. Za zavezništvo manj relevantne zmogljivosti bi lahko popolnjevali tudi z naborniki. Njihovo usposabljanje bi moralo potekati najmanj do vodne ravni. Hkrati bi pomenili vir moštva za popolnjevanje potreb po vodjih tako v stalni kot rezervni sestavi. Ustreznemu moštvu bi se po odsluženem vojaškem roku ponudila tudi možnost nadaljnje pogodbene službe $\mathrm{v}$ stalni sestavi, ki bi trajala od enega do treh let (ena do dve rotaciji v MOM). Ob tem predlogu bi bila nujna analiza rezultatov naborništva pred letom 2003. Vsekakor pa menimo, da je nujnih več kot štiri mesece služenja vojaškega roka za usposobitev dostojne lahke pehote na vodni ravni. ${ }^{38}$ Večina nabornikov in tudi pogodbenih pripadnikov stalne sestave bi se po končani službi razporedila v rezervno sestavo $\mathrm{v}$ potrebnem obsegu in trajanju. Neizpolnjevanje minimalnih meril služenja v rezervi bi moralo pomeniti odpust iz nje, čemur bi moral slediti tudi ukrep, ki bi posameznike odvračal od izogibanja temu služenju. Ključne bi bile tudi delne mobilizacijske vaje, s katerimi bi preverjali odzivnost mobilizacijskega sistema SV. Po koncu službe v rezervi bi posamezniki ostali na seznamih vojaške strateške rezerve, a brez obveznosti v miru.

\footnotetext{
${ }^{36}$ To v praksi pomeni, da v bistvu potrebujemo enako velike sisteme PINK, ViU, MSSVT itn. ne glede na to, ali imamo dva polka pehote ali jih je pet ali petnajst. Razlike so $v$ rezultatih teh podsistemov, ne toliko $v$ njihovi velikosti.

${ }_{37}$ Seveda je mogoče nekatere podsisteme nasloniti tudi na civilne, toda ne vseh in ne v pretežnem delu, ker sicer vojska izgubi svoj profesionalni potencial.

${ }^{38}$ Lind in Thiele ocenjujeta, da je za transformacijo frontne pehote v lahko pehoto potrebnih 20 tednov (5 mesecev), in sicer ob predpostavki, da so že pridobili to, čemur bi v SV dejali osnovno vojaško evidenčno dolžnost (VED), kar za vojaka pehote v SV traja približno pet mesecev. Ti časi veljajo za transformacijo frontne pehote v lahko pehoto. Če celoten koncept že v izhodišču zastavimo drugače, je skupni čas mogoče precej skrajšati.
} 
Sklep »Od stotih mož jih deset sploh ne bi smelo biti tam, osemdeset jih samo predstavlja tarčo, devet je pravih borcev in lahko smo veseli, da jih imamo, saj je zaradi njih bitka sploh možna. Ampak eden, eden je bojevnik, in on bo vse druge pripeljal nazaj. $\ll^{39}$ Heraklit (500 pr. n. š.)

Za delovanje in uspešno spopadanje s sovražnikom v četrti generaciji vojskovanja potrebuje SV drugačno organizacijsko kulturo. Kot piše Poole, se zmogljivosti lahke pehote oziroma gverilske vojske in visoko tehnološke zmogljivosti manevrskega vojskovanja ne izključujejo (Poole, 2001, str. 11). SV sama zase ne more biti uspešna v konfliktih četrte generacije, sploh pa ne v konfliktih visoke intenzivnosti, ki so njihov sestavni del. Hkrati se jim ne more izogniti. Samo če bomo aktivno sodelovali v zavezniških povezavah lahko pričakujemo, da bomo lahko soodločali in odločali o svoji usodi. To pa ne more in ne sme pomeniti, da vse svoje sile usmerjamo $\mathrm{v}$ zavezništvo. V zavezništvo moramo prispevati vojaško relevantne zmogljivosti in izpolnjevati zaveze, ki jih sprejemamo. Pri tem zaveznikov ne zanima, koliko sredstev namenjamo za obrambo, temveč le, kaj prispevamo k skupni varnosti. Ob tem bomo morali za varnost na svojem ozemlju poskrbeti predvsem sami. In za to je najprimernejši koncept lahke pehote, ki zagotavlja množičnost in prilagodljivost, da jo je mogoče uporabiti v celotnem spektru nalog, od pomoči pri zaščiti in reševanju, $v$ mirovnih operacijah ter operacijah v podporo stabilnosti in obnovi, do čisto vojaških operacij. Četudi organizacijska struktura lahke pehote ni najprimernejša za operacije visoke intenzivnosti, to še ne pomeni, da to velja tudi za njeno organizacijsko kulturo.

Vse našteto se ne bo zgodilo samo po sebi, ne z zapisom želja na kos papirja ne $\mathrm{z}$ razpravami oziroma posveti $\mathrm{v}$ parlamentu ali s strokovnimi debatami. Kulturne spremembe se začnejo z zaželenim vedenjem in voditelji, ki ga podpirajo, za kar morajo biti zagotovljene tudi ustrezne spodbude in kazni.

Priprava nujnih sprememb in razmislek o njih ne zahtevata posebnih virov. Zahtevata pa intenzivno komunikacijo SV s politiko in družbo, ki temelji na strokovnih podlagah. Nadaljnja uveljavitev nujnih sprememb in vzpostavitev obrambnih zmogljivosti, ki bodo ustrezale četrti generaciji vojskovanja, bosta zahtevali precej več od trenutnih 0,9 odstotka BDP. Zaradi načrtnega zapostavljanja in zlorabljanja obrambnih zmogljivosti v zadnjih 20 letih bo to žal precej več, kot so trenutne politične obljube. Dolgoročno bi se ta znesek moral stabilizirati okrog 1,5 odstotka BDP, kar je še vedno manj, kot bi morali namenjati za varnost, če bi se odločili za samostojno obrambno držo $(2,5-2,7 \text { odstotka })^{40}$.

\footnotetext{
39 „Out of every one hundred men, ten shouldn't even be there, eighty are just targets, nine are the real fighters, and we are lucky to have them, for they make the battle. Ah, but the one, one is a warrior, and he will bring the others back."

${ }^{40}$ Ocene so avtorjeve in temeljijo na metodologiji, ki je bila podrobneje opisana v prejšnjem prispevku (Potočnik, 2017, str. 54).
} 


\section{Literatura}

1. Državni zbor RS, 2011. Resolucija o splošnem dolgoročnem programu razvoja in opremljanja Slovenske vojske do leta 2025 (ReSDPRO 2025). Uradni list RS, št. 99/2010, $z$ dne 7. 12. 2010.

2. FKSM 71-8, 2010. Armor/Cavalry reference data; Brigade combat teams. US Army Armor Center, Fort Knox, KY.

3. FM 21-18, 1990. Foot Marches. HQ Department of the Army, Washington, DC.

4. Furlan, B. (in drugi), 2006. Vojaška doktrina. Defensor, Ljubljana.

5. Grizold A., 1999. Obrambni sistem Republike Slovenije. MNZ, Visoka policijskovarnostna šola, Ljubljana.

6. KnapikJ., 1989. Loads carried by soldiers: Historical, Psysiological, Biomechanical and Medical Aspects. US Army Research Institute of Enviromental Medicine, Natick, Massachusetts.

7. Lind, W.S., in Thiele, G.A., 2015. 4TH Generation Warfare Handbook. Castilia House. Kouvola, Finland (Kindle book).

8. McMichael, S.R., 1987. A Historical Perspective on Light Infantry. Research survey/ Combat Studies Institute; no. 6. U.S.A. CGSC, Fort Leavenworth, KS. http://usacac.army. mil/cac2/cgsc/carl/download/csipubs/HistoricalPerspectiveonLightInfantry.pdf).

9. NATO, 2016. Bi-Sc Agreed Capability Codes and Capability Statements. Belgium: Supreme Allied Commander, Europe.

10. Pišlar, M., 2016. Denarja za obrambne izdatke je premalo, če želimo SV obdržati. pogovor z generalnim direktorjem Direktorata za obrambno politiko Primožem Šavcem. Intervju v reviji SV št. 4, april 2016, MO, Ljubljana.

11. Poole, H. J., 2001. Phantom soldier - the enemy's answer to U.S. firepower. Posterity Press, Emerald Isle, NC.

12. Potočnik, V., 2017. Četrta generacija vojskovanja 2. del: celovita prenova nacionalnovarnostnega sistema. SVI, MO, Ljubljana.

13. Selig, R.A. \& Skaggs, C.D., 1991. Treatise on Partisan Warfare (Abhandlung uber den kleinen Krieg); Johan Ewald. Greenwod Press, Westport, CT.

14. Vandergriff, D.E., 2006. Rasing the Bar; Creating and Nurturing Adaptability to Deal with the Changing Face of War. Center for Defence Information, Washington, D.C.

15. Vlada RS, 2004. Zakon o obrambi (uradno prečiščeno besedilo). Ljubljana: Uradni list RS, št. 103/04 in št. 95/15.

16. Vlada RS, 2013. Srednjeročni obrambni program Republike Slovenije 2013-2018. Ljubljana: št. 80300-1/2013/3, z dne 1. 2. 2013.

17. Vlada RS, 2016. Srednjeročni obrambni program Republike Slovenije 2016-2020. Ljubljana: št. 80300-2/2016/3, z dne 17. 2. 2016.

18. Vlada RS, 2016. Sklepi strateškega pregleda obrambe 2016. Ljubljana: št. 80400 1/2016/6, z dne 22. 12. 2016. 